\title{
Efektifitas Pupuk Fosfat Alam pada Pertumbuhan dan Produksi Tanaman Jagung (Zea mays L.)
}

\section{Effectiveness of Natural Phosphate Fertilizers on Maize (Zea mays L) Growth and Production}

\author{
Sugiono $^{1}$ dan Eny Wahyuning Purwanti ${ }^{2}$ \\ 1) BPTP Jawa Timur J1 Raya Karangploso Km 4, PO BOX 188 Malang. \\ ${ }^{2)}$ Politeknik Pembangunan Pertanian Malang \\ e-mail: *astro_bptp@yahoo.co.id
}

\begin{abstract}
ABSTRAK
Fosfat Alam sebagai substitusi pupuk SP-36 berpotensi mereduksi biaya produksi pada budidaya jagung. Fosfat alam yang digunakan memiliki kandungan $\mathrm{P}_{2} \mathrm{O}_{5}$ total 15,70\%. Lokasi penelitian di Desa Keboan, Kec. Ngusikan, Kabupaten Jombang, pada MK II tahun 2017. Percobaan menggunakan rancangan acak kelompok, 9 perlakuan 3 ulangan. Perlakuan meliputi berbagai dosis pupuk Fosfat Alam termasuk kontrol. Kelayakan usahatani dianalisis dengan nilai Benefit Cost Ratio. Sedangkan efektivitas pupuk Fosfat Alam diukur menggunakan metode Relative Agronomic Effectiveness terhadap pupuk rekomendasi. Hasil menunjukkan bahwa perbedaan dosis aplikasi pupuk Fosfat Alam berpengaruh terhadap tinggi tanaman, panjang tongkol, diameter tongkol dan bobot tongkol basah. Perlakuan terbaik adalah Fosfat Alam 100 + Urea $450+\mathrm{KCl} 100 \mathrm{~kg} / \mathrm{ha}$. Perlakuan ini menghasilkan efek yang sama jika dibandingkan dengan perlakuan dosis pupuk rekomendasi (Urea $350+$ Phonska $450 \mathrm{~kg} / \mathrm{ha}$ ). Untuk pipilan kering perlakuan tersebut menghasilkan 7,90 t/ha dengan B/C ratio 1,23. Hasil ini juga tidak berbeda nyata jika dibandingkan dengan perlakuan pupuk rekomendasi dengan hasil pipilan kering 7,66 t/ha dengan B/C Ratio 2,22. Sedangkan nilai RAE perlakuan sebesar 104,39. Fosfat Alam dengan $\mathrm{P}_{2} \mathrm{O}_{5}$ 15,70\% dapat digunakan sebagai substitusi pupuk $P$ dengan dosis $100 \mathrm{~kg} / \mathrm{ha}$ atau dalam dosis pupuk majemuk (Fosfat Alam $100+$ Urea $450+\mathrm{KCl} 100 \mathrm{~kg} / \mathrm{ha}$ ).
\end{abstract}

Kata kunci: Jagung, produktivitas, fosfat alam, dosis pupuk,.

\section{ABSTRACT}

Natural Phosphate has potential as SP-36 substitute. Natural phosphate contents of $15.70 \%$ total $\mathrm{P}_{2} \mathrm{O}_{5}$ value. Research conducted in Keboan Village, Ngusikan, Jombang, in the second dry season of 2017. Randomized block design was used with 9 treatments and 3 replications. Treatment consists of different dosage of Natural Phosphate use as fertilizer including control. B/C ratio was calculated to analyze the farming feasibility. The effectiveness of Natural Phosphate fertilizer was measured using the Relative Agronomic Effectiveness method compared to fertilizer recommendation treatment. The results showed that the application of Natural Phosphate fertilizer had effect on plant height, corncob length, diameter and wet weight. The best treatment is Natural Phosphate $100+$ Urea $450+\mathrm{KCl} 100 \mathrm{~kg} / \mathrm{ha}$. It showed similarity with the result of fertilizer recommendation treatment (Urea $350+$ Phoska $450 \mathrm{~kg} / \mathrm{ha}$ ). The dry shell production is $7.90 \mathrm{t} / \mathrm{ha}$ with $\mathrm{B} / \mathrm{C}$ ratio 1.23 . It's also not significantly different with fertilizer recommendation treatment ( $7.66 \mathrm{t} / \mathrm{ha}$ dry shell productivity and $2.22 \mathrm{~B} / \mathrm{C}$ Ratio). The RAE value is 104.39. Therefore natural phosphate with $\mathrm{P}_{2} \mathrm{O}_{5}$ value $15.70 \%$ can substitute Phospat fertilizer. 
If it used as complete fertilizer the compotition would be Natural Phosphate $100+$ Urea $450+$ $\mathrm{KCl} 100 \mathrm{~kg} / \mathrm{ha}$ ).

Keywords: Maize, productitivity, natural phosphate, fertilizer dosage.

\section{PENDAHULUAN}

Diantara tanaman palawija, jagung merupakan komponen utama dalam pakan ternak dan mencapai sekitar $51 \%$ dari komposisi pakan (Swastika et al., 2005). Jagung merupakan tanaman pangan terpenting kedua setelah padi sebagai sumber karbohidrat, serta digunakan sebagai bahan baku industi, seperti minyak goreng (corn oil), gula rendah kalori, tepung jagung (maizena) dan bahan bakar ramah lingkungan (bioetanol). Produksi jagung tahun 2015 di Jawa timur, luas panen 1.213.654 ha produksi 6.131 .163 ton pipilan kering, luas panen Nasioanal 3.787.367 ha produksinya 19.612 .435 ton pipilan kering. Luas panen Jawa Timur $32.04 \%$ dari luas panen Nasianal dan 31,26\% produksi Nasional, menempatkan Jawa Timur sebagai penghasil jagung tertinggi dari semua propinsi, di tinjau dari luas panen dan produksi (BPS, 2015).

Salah satu upaya meningkatkan produksi jagung, baik dengan pemupukan, Banyak pupuk yang telah diuji untuk tanaman jagung, baik berupa pupuk organik maupaun an organik. Salah satunya pupuk an organik yang mengandung unsur $\mathrm{P}$ (Fosfat). Sumber pupuk $\mathrm{P}$ yang umumnya digunakan oleh petani sekarang ini adalah pupuk SP-36. Pemberian pupuk $\mathrm{P}$ pada tanah tegalan yang merupakan basis pengembangan tanaman pangan khususnya jagung di Jawa banyak permasalahan (Kasno et.al, 1998).

Pengelolaan lahan jagung dengan pemupukan secara rasional merupakan upaya meningkatkan efisiensi biaya produksi dan mengoptimalkan peningkatan produksi jagung, menginggat bahwa degradasi tanah menyebabkan terjadinya penurunan produktivitas tanah (Sarief. 1985), Rendahnya tingkat kesuburan sangat dipengaruhi oleh faktor iklim, terutama

9 |Jurnal Agriekstensia Vol. 18 No. 1 Juli 2019 curah hujan yang tinggi, yakni mencapai 1500-6000 mm/tahun (Puslitanak. 2004).

Penggunaan pupuk yang efisien pada dasarnya adalah memberi pupuk baik unsur hara makro maupun hara mikro dalam jumlah, macam dan bentuk yang sesuai dengan kebutuhan tanaman, dengan cara dan saat pemberian yang tepat sesuai kebutuhan dan tingkat pertumbuhan tanaman jagung. Kelebihan pemberian pupuk selain merupakan pemborosan usahatani, juga mengganggu keseimbangan unsur-unsur hara dalam tanah dan penyebab terjadinya pencemaran lingkungan. Pemupukan merupakan salah satu komponen teknologi yang berkontribusi terhadap tingkat produksi jagung, dengan prinsip empat tepat yaitu tepat: jenis, dosis, waktu dan cara (Adiningsih et al. 1989; Moersidi et al.1991; Rochayati et al. 1991).

Penambahan unsur melalui pemupukan yang dilakukan secara tidak berimbang dapat menyebabkan terjadinya pengurasan beberapa unsur hara dalam tanah secara cepat. Kondisi semacam ini mengakibatkan terjadinya penurunan kesuburan tanah (Tisdale et al. 1985; Karama, 2000). Ketersediaan unsur hara yang cukup sangat penting untuk pertumbuhan dan hasil tanaman. Salah satu faktor penyebab tidak optimalnya sarapan unsur hara oleh tanaman adalah tingkat keasaman tanah $(\mathrm{pH})$. Pada tingkat keasaman yang rendah, unsur hara dapat menjadi tak tersedia akibatnya unsur tersebut tidak dapat diserap oleh tanaman (Tisdal dan Nelson, 1975). Beberapa hal yang dapat menyebabkan $\mathrm{pH}$ tanah rendah adalah, batuan induk tanah memang bersifat masam, infiltrasi unsur S (sulfur) dari daerah lain yang berlebihan melalui aliran air, atau lebih dominannya pemupukan yang mengandung banyak unsur S seperti ZA dan ZK.

Peluang untuk penggunaan Pupuk Fosfat Alam di tanah pertanian di Indonesia yang relatif sangat tinggi penggunaannya, 
konversi Fosfat Alam menjadi pupuk P yang mudah larut memerlukan biaya tinggi, pemborosan energi dan memerlukan jumlah bahan kimia seperti asam sulfat dan asam fosfat yang besar. Oleh karena itu diperlukan peningkatan efisiensi penggunaan pupuk $\mathrm{P}$, salah satunya adalah menggunakan Fosfat Alam sebagai pupuk secara langsung (direct application phosphate rock/DAPR).

Ketersedian bahan baku pupuk Fosfat Alam di negara kita sangat tinggi, Pada umumnya deposit Fosfat Alam di Indonesia mempunyai kadar total $\mathrm{P}_{2} \mathrm{O}_{5}$ sangat bervariasi dari rendah sampai sedang dan ada beberapa deposit yang mencapai kadar sampai 40\% $\mathrm{P}_{2} \mathrm{O}_{5}$. (Balai Penelitian Tanah). Pemberian SP-36 dengan dosis 40 $\mathrm{kg} \mathrm{P}$ ha meningkatkan bobot pipilan jagung kering 1,5 kali dibanding tanpa pupuk $\mathrm{P}$ (Purnomo, 2007).

Kemudian di alam, fosfor terdapat dalam dua bentuk, yaitu senyawa fosfat organik (pada tumbuhan dan hewan) dan senyawa fosfat anorganik (pada air dan tanah). Di larutan tanah fosfor sering berada dalam bentuk tidak tersedia bagi tanaman dikarenakan berada dalam bentuk terfiksasi, sehingga diperlukan upaya pemberian fosfor melalui pemupukan (Pian, 2010). Pengaruh Fosfat Alam terhadap tanah dan tanaman erat kaitannya dengan sifat kelarutan dari Fosfat Alam itu sendiri. Fosfat Alam dalam bentuk trikalsik yang digunakan pada tanah pertanian masam umumnya berfungsi sebagai amandemen dan/atau pupuk. Kelarutan dalam tanah tergantung dari faktor, konsentrasi ion fosfat (Khasawneh et al., 1978 dalam Idris, 1993) dan ion kalsium dalam tanah (Walte, 1978 dalam Idris, 1995).

Untuk mengatasi kekurangan nutrisi terutama unsur-unsur nitrogen, fosfor, dan kalium, unsur fosfor diperlukan dalam jumlah lebih sedikit daripada unsur nitrogen. Fosfor merupakan komponen penyusun beberapa enzim, protein, ATP, RNA , dan DNA. ATP penting untuk proses transfer energi, sedangkan RNA dan DNA menentukan sifat genetik tanaman. Unsur $\mathrm{P}$ juga berperan pada pertumbuhan benih, akar, bunga, dan buah. Dengan membaiknya struktur perakaran sehingga daya serap nutrisi pun lebih baik. Bersama dengna kalium, fosfor dipakai untuk merangsang pembungaan.

Fungsi pupuk posfat (P) bagi tanaman berperan dalam proses: a). respirasi dan fotosintesis, b). penyusunan asam nukleat, c). pembentukan bibit tanaman dan penghasil buah, d). Perangsang perkembangan akar, sehingga tanaman akan lebih tahan terhadap kekeringan dan e). Mempercepat masa panen sehingga dapat mengurangi resiko keterlambatan waktu panen. Melihat Fungsi dan Kegunaan unsur Fosfor, kebutuhan Pupuk Fosfat Alam diharap dapat membantu permasalahan di tanah pertanian pada umumnnya yang sebagian besar tanah masam. Pupuk Fosfat Alam adalah pupuk Anorganik dengan mengandung unsur hara $\mathrm{P}_{2} \mathrm{O}_{5}$ Total $15,70 \%$ yang diharapkan mampu memenuhi kebutuhan akan unsur hara tanaman, terutama tanaman jagung diharapkan mampu meningkatkan pertumbuhan dan produksi tanaman.

Tujuan dengan mengetahui efektivitas pupuk anorganik fosfat alam terhadap pertumbuhan dan produksi tanaman jagung adalah sebagai pupuk alternatif atau subsitusi pupuk mengandung unsur $\mathrm{P}_{2} \mathrm{O}_{5}$ yang beredar dipasar dan sebagian besar adalah pupuk bersubsidi. Dimana permasalahan yang sering adalah waktu pupuk dibutuhkan kadang ada permasalahan dalam penyediaan dan diharap dengan aplikasi pupuk fosfat alam pendapatan usahatani dapat meningkat.

\section{METODE PENELITIAN}

Komposisi Pupuk Fosfat Alam, dari analisis kandungan hara pupuk Fosfat Alam yang dilakukan oleh SUCOFINDO. No. 148.OL/SR.320/B.5.4/1/2017, disajikan pada tabel 1.

Tabel 1. Kandungan hara pupuk Fosfat Alam

\begin{tabular}{lccl}
\hline Parameter & Satuan & Hasil & Metoda \\
\hline $\begin{array}{l}\mathrm{P}_{2} \mathrm{O}_{5} \text { Total (dry } \\
\text { basic) }\end{array}$ & $\%$ & 15,70 & $\begin{array}{l}\text { SNI 02-3776 - 2005 } \\
\text { (poin 6.1.1) }\end{array}$ \\
$\mathrm{P}_{2} \mathrm{O}_{5}$ soluble in & $\%$ & 15,64 & SNI 02-3776 - 2005 \\
\hline
\end{tabular}


Efektifitas Pupuk Fosfat Alam pada pertumbuhan dan Produksi (Sugiono dan Eny Wahyuning Purwanti)

\begin{tabular}{|c|c|c|c|}
\hline $\begin{array}{l}\text { citric acid 2\% (dry } \\
\text { basic) }\end{array}$ & & & (poin 6.1.2) \\
\hline $\begin{array}{l}\text { Moisture/ Woter } \\
\text { kontent }\end{array}$ & $\%$ & 4,83 & $\begin{array}{l}\text { SNI 02-3776 - } 2005 \\
\text { (poin 6.2) }\end{array}$ \\
\hline Cd (dry basic) & ppm & 4,7 & $\begin{array}{l}\text { SNI 02-3776 - } 2005 \\
\text { (poin 6. 4, 1) }\end{array}$ \\
\hline $\mathrm{Pb}$ (dry basic) & ppm & 7,0 & $\begin{array}{l}\text { SNI 02-3776- } 2005 \\
\text { (poin } 6.4,2 \text { ) }\end{array}$ \\
\hline As (dry basic) & ppm & 2,78 & $\begin{array}{l}\text { SNI 02-3776 - } 2005 \\
\text { (poin 6.5) }\end{array}$ \\
\hline Hg (dry basic) & ppm & 1,00 & $\begin{array}{l}\text { SNI 02-3776 - } 2005 \\
\text { (poin 6. 4,3) }\end{array}$ \\
\hline \multicolumn{4}{|l|}{ Size test : (ASTM) } \\
\hline $\begin{array}{l}\text { Passing through } \\
\text { mesh } 25(0,707 \\
\mathrm{mm})\end{array}$ & ppm & 99,25 & $\begin{array}{l}\text { SNI 02-3776- } 2005 \\
\text { (poin 6. 3) }\end{array}$ \\
\hline $\begin{array}{l}\text { Passing through } \\
\text { mesh } 80(0,177 \\
\text { mm })\end{array}$ & ppm & 54,05 & \\
\hline
\end{tabular}

Penelitian dilakukan di Desa Keboan, Kec. Ngusikan, Kab.Jombang, pada MK II (bulan Juni s/d Oktober) tahun 2017. Penelitian dilaksanakan pada lahan sawah irigasi, pada MK-II tahun 2017. Bahan: menggunakan jagung hibrida dengan varietas disesuaikan yang dominan ditanam petani, pupuk yang diuji fosfat alam, pupuk Urea, pupuk $\mathrm{KCl}$, Phonska dan peralatan yang digunakan untuk penelitian. Varetas mengunakan jagung hybrida BISI-18 yang dominan ditanam petani dilokasi penelitian.

Sebelum penelitian dilaksanakan, dilakukan pengambilan sampel tanah di lokasi untuk mengetahui kandungan hara sebelum perlakuan. Hasil analisa tanah di Labratorium Tanah BPTP Balitbngtan Jawa Timur (Tabel.2) adalah sebagai berikut, $\mathrm{pH}$ Netral, kandungan $\mathrm{C}$-organik adalah rendah dan $\mathrm{N}$ total rendah. Kandungan $\mathrm{P}_{2} \mathrm{O}_{5}(\mathrm{ppm})$ sangat tinggi dan $\mathrm{Ca}$-dd rendah, KTK sangat tinggi dan jenis tanah Liat.

Tabel 2. Analisa tanah di lokasi efektifitas pupuk anorganik Fosfat Alam

\begin{tabular}{|c|c|c|c|}
\hline No. & Jenis Analisis & Nilai Penetapan & Harkat \\
\hline 1. & Kadar air & 10,83 & \\
\hline 2. & $\mathrm{pH}-\mathrm{H}_{2} \mathrm{O}$ & 6.8 & Netral \\
\hline 3. & $\mathrm{pH}-\mathrm{KCl}$ & 5,4 & \\
\hline 4. & $\mathrm{C}$ - organik (\%) & $1,53 \%$ & Rendah \\
\hline 5. & $\mathrm{~N}-\operatorname{total}(\%)$ & $0.18 \%$ & Rendah \\
\hline 6. & $\mathrm{P}_{2} \mathrm{O}_{5}(\mathrm{ppm})$ & $87 \mathrm{ppm}$ & Sangat tinggi \\
\hline \multirow[t]{2}{*}{7.} & $\mathrm{~K}$-tersedia $(\mathrm{me} / 100 \mathrm{~g})$ & 0,33 & Rendah \\
\hline & $\mathrm{Na}$ & 0,09 & Sangat tinggi \\
\hline 8. & $\mathrm{Mg}$ & 1,33 & Sedang \\
\hline 9. & $\mathrm{Ca}$ & 4,08 & Rendah \\
\hline 10. & KTK (me/100 g) & 44,99 & Sangat Tinggi \\
\hline \multirow[t]{4}{*}{11.} & Tekstur: & & \\
\hline & - Pasir (\%) & $4 \%$ & \\
\hline & - Debu (\%) & $19 \%$ & \\
\hline & - Liat (\%) & $77 \%$ & Liat \\
\hline
\end{tabular}

Penelitian menggunakan Rancangan Acak Kelompok yang diulang 3 kali dengan 9 perlakuan, yang menggunakan kombinasi pupuk Fosfat Alam (Tabel 3) dan kandungan hara perlakuan.

Tabel 3. Perlakuan Kombinasi Pupuk Fosfat Alam dan Kandungan Unsur Hara Pupuk.

\begin{tabular}{cccccccc}
\hline \multirow{2}{*}{ Perlk } & \multicolumn{2}{c}{ Perlakuan Macam dan Dosis Pupuk (kg/ha) } & \multicolumn{3}{c}{ Kandungan Unsur Hara (kg/ha) } \\
\cline { 2 - 5 } & Urea & Phonska & $\mathrm{KCl}$ & Fosfat Alam & $\mathrm{N}$ & $\mathrm{P}_{2} \mathrm{O}_{5}$ & $\mathrm{~K}_{2} \mathrm{O}$ \\
\hline $\mathrm{A}$ & 0 & 0 & 0 & 0 & 0 & 0 & 0 \\
$\mathrm{~B}$ & 450 & 0 & 0 & 0 & 207 & 0 & 0 \\
$\mathrm{C}$ & 350 & 450 & 0 & 0 & 228,5 & 67,5 & 67,5 \\
$\mathrm{D}$ & 450 & 0 & 0 & 100 & 207 & 15 & 0 \\
$\mathrm{E}$ & 450 & 0 & 0 & 200 & 207 & 30 & 0 \\
F & 450 & 0 & 0 & 300 & 207 & 45 & 0 \\
$\mathrm{G}$ & 450 & 0 & 100 & 100 & 207 & 15 & 60 \\
$\mathrm{H}$ & 450 & 0 & 100 & 200 & 207 & 30 & 60 \\
$\mathrm{I}$ & 450 & 0 & 100 & 300 & 207 & 45 & 60 \\
\hline
\end{tabular}

11 Jurnal Agriekstensia Vol. 18 No. 1 Juli 2019 
Pengolahan tanah dilakukan intensif, dengan membajak 2 kali, kemudian diratakan dan dibuat saluran drainase yang juga berfungsi sebagai pembatas petak utama. Luas petak percobaan adalah $6 \mathrm{~m}$ x 6 $\mathrm{m}$ atau disesuaikan luas lahan yang tersedia dengan jarak tanam $75 \mathrm{~cm}$ x $20 \mathrm{~cm}, 1$ tanaman tiap lubang (populasi 62.500 tanaman/ha) varietas jagung menggunakan jagung hibrida BISI-18.

Pestisida yang digunakan adalah karbofuran dengan dosis 0,5 - 1 gr pada lubang tanam, yang diberikan pada waktu tanam. Pupuk kompos 2 ton/ha di aplikasi bersamaan waktu tanam (untuk penutup lubang tanam. Aplikasi perlakuan pemupukan sebanyak 3 kali, yaitu umur 15 HST, pupuk ke-2 umur 28 HST dan umur 40 HST.

Penyiangan dilakukan 2 kali, pada umur 15 HST bersamaan dengan pupuk ke-1 dan umur 26 HST dilakukan penyiangan dan persamaan dengan pembumbunan. Untuk mencegah penggerek pucuk pada umur 30 HST diberikan karbufuran yang di aplikasikan dititik tumbuh. Pengendalian hama dan penyakit menggunakan prinsif PHT dengan pengamatan berkala dan ambang kendali sehingga tanaman terhindar dari gangguan hama dan penyakit dapat menurunkan hasil.

Panen dilakukan pada saat klobot tongkol jagung sudah mengering. Jagung dipanen kondisi masak fisiologis sesuai dengan agroekologi daerah setempat. Jagung di batangnya dibiarkan mengering kering sehingga jagung dipanen yaitu ketika klobot sudah kering berwarna coklat dan rambut jagung hitam mengering

Parameter yang diamati meliputi: tinggi tanaman pada $70 \mathrm{HST}$, pengamatan hasil panen: Bobot glondong panen, panjang tongkol $(\mathrm{cm})$, bobot pipilan kering (t/ha). Tingkat serangan hama penyakit secara berkala dengan mengunakan nilai / score. Data yang tekumpul kemudian dianalisa dengan analisis ragam, untuk mengetahui perbedaan antar perlakuan dilanjutkan dengan uji BNT. Sedangkan untuk mengetahui dosis optimal pupuk Fosfat 12 |Jurnal Agriekstensia Vol. 18 No. 1 Juli 2019
Alam di analisis dengan analisis kuadratik, kemudian untuk mengetahui keuntungan secara ekonomi dalam budidaya Jagung dilakukan dengan analisis $\mathrm{B} / \mathrm{C}$ ratio.

Efektivitas pupuk Anorganik Fosfat Alam didekati menggunakan metode Relative Agronomis Effectiveness (RAE). Masing-masing perlakuan diuji terhadap pupuk standar (dalam percobaan ini adalah perlakuan 2). RAE adalah perbandingan antara kenaikan hasil karena penggunaan suatu pupuk dengan kenaikan hasil menggunakan pupuk standar dikalikan 100 (Machay et al., 1984; Chien, 1996).. Tujuan perlakuan tanpa pupuk untuk menghitung RAE. Rumus RAE sebagai berikut :

$\mathrm{RAE}=\frac{\text { Hasil dari pupuk yang diuji }- \text { kontrol }}{\text { Hasil dari pupuk standar }- \text { kontrol }} \times 100 \%$

\section{HASIL DAN PEMBAHASAN}

\section{Pertumbuhan Tanaman.}

Hasil pengamatan tinggi tanaman, dilakukan pada pertanaman mencapai tinggi moptimum antara umur 70 hst. Pada semua perlakuan pupuk tinggi tanaman menunujukkan tinggi yang tidak berbeda nyata antara $71,73 \mathrm{~cm}-$ $81,5 \mathrm{~cm}$. menujukkan tinggi tanaman terendah 46,2 cm pada control untuk menghitung Nilai RAE. Pengamatan jumlah tanaman perpetak juga tidak menunjukkan perbedaan yang nyata pada semua perlauan pemupukan. Karena Fosfor/Fosfat diambil oleh akar dalam bentuk $\mathrm{H}_{2} \mathrm{PO}_{4}^{-}$\& $\mathrm{HPO}_{4}{ }^{-}$ Menurut (Sugih, 2011), sebagian besar fosfor di dalam tanaman adalah sebagai zat pembangun dan terikat dalam senyawasenyawa organik dan hanya sebagian kecil terdapat dalam bentuk anorganik sebagai ion-ion phosphat. Beberapa bagian tanaman sangat banyak mengandung zat ini, yang berguna pembiakan generatif, seperti daundaun bunga, tangkai sari, kepala sari, butir tepung sari, daun buah dan bakal biji. Jadi untuk pembentukan bunga dan buah sangat banyak diperlukan unsur fosfor . 
Tabel 4. Pengamatan Tinggi Tanaman dan Jumlah Tanaman Perpetak, Efektifitas Pupuk Anorganik Fosfat Alam.

\begin{tabular}{cccccccc}
\hline & Perlk & \multicolumn{3}{c}{ Jenis dan Dosisi Pupuk (kg/ha) } & \multicolumn{2}{c}{ Hasil Pengamatan } \\
\cline { 2 - 7 } & $\begin{array}{c}\text { Fosfat } \\
\text { Alam }\end{array}$ & Urea & Phonska & KCl & Tinggi Tanaman & Jml tan. Per petak \\
\hline A & 0 & 0 & 0 & 0 & $46.20 \mathrm{~b}$ & $104.00 \mathrm{~b}$ \\
B & 0 & 450 & 0 & 0 & $80.00 \mathrm{a}$ & $163.33 \mathrm{a}$ \\
C & 0 & 350 & 450 & 0 & $79.16 \mathrm{a}$ & $151.33 \mathrm{a}$ \\
$\mathrm{D}$ & 100 & 450 & 0 & 0 & $72.66 \mathrm{a}$ & $150.33 \mathrm{a}$ \\
$\mathrm{E}$ & 200 & 450 & 0 & 0 & $71.73 \mathrm{a}$ & $150.00 \mathrm{a}$ \\
$\mathrm{F}$ & 300 & 450 & 0 & 0 & $79.43 \mathrm{a}$ & $188.33 \mathrm{a}$ \\
$\mathrm{G}$ & 100 & 450 & 0 & 100 & $72.47 \mathrm{a}$ & $150.33 \mathrm{a}$ \\
$\mathrm{H}$ & 200 & 450 & 0 & 100 & $74.80 \mathrm{a}$ & $153.33 \mathrm{a}$ \\
$\mathrm{I}$ & 300 & 450 & 0 & 100 & $81.50 \mathrm{a}$ & $154.00 \mathrm{a}$ \\
\hline
\end{tabular}

Angka selajur yang diikuti oleh huruf yang sama tidak berbeda nyata berdasarkan uji lanjut DMRT pada taraf 0.05.

berbeda nyata dengan pada perlakuan pupuk

Jumlah tanaman yang terendah di tunjukkan pada perlakuan tanpa pemupukan, sehingga jumlah tanaman yang dapat menghasilkan jumlah tongkol juga rendah. Pada kontrol tanpa pemupukan tanaman yang jelek tidak dapat menghasilak tongkol diambil lebih dahulu diguanakan untuk pakan ternak, yang ditinggal tanaman yang dapat menghasilkan tongkol saja dengan jumlah rata-rata 100,6 tanaman.

Komponen hasil pada waktu panen, pengamatan jumlah tongkol per hektar yang tinggi pada perlakuan pupuk Fosfat Alam $100 \mathrm{~kg}+$ Urea $450+\mathrm{KCl} 100 \mathrm{~kg} /$ hektar 54.76 berbeda nyata dengan tanpa pemupukan dan perlakuan $\mathrm{F}$ tanpa $\mathrm{KCl}$. pada perlakuan pemupukan rekomendasi tidak
Fosfat Alam lainnya. Jumlah tongkol yang terendah pada perlakuan A tanpa aplikasi pemupukan dengan jumlah tongkol 24.952 . Panjang tongkol pada semua perlakuan baik pada pupuk rekomendasi maupun perlakuan Fosfat Alam semua tidak berbeda nyata. Panjang tongkol Fosfat Alam 300 + Urea $450 \mathrm{~kg} /$ hektar dan perlakuan pupuk rekomendasi Urea 350 + Phonska $450 \mathrm{~kg} / \mathrm{ha}$ menunjukkan hasil tongkol paling panjamg tetapi tidak berbeda nyata dengan perlakuan pupuk yang lainya. Jumlah tonggol tertinggi ditunjukkan pada perlakuan G (100 Fosfat Alam+450 Urea+100 KCl, tidak berbeda nyata dengan perlakuan $\mathrm{C}$ pupuk rekomendasi dan Perlakuan B,D,E,F H dan I.

Tabel 5. Pengamatan Jumlah, Panjang dan Diameter Tongkol Efektifitas Pupuk Anorganik Fosfat Alam.

\begin{tabular}{|c|c|c|c|c|c|c|c|}
\hline \multirow[t]{2}{*}{$\mathrm{P}$} & \multicolumn{4}{|c|}{ Jenis dan Dosisi Pupuk (kg/ha) } & \multicolumn{2}{|c|}{ Hasil Pengamatan } & \multirow[b]{2}{*}{ Diameter Tongkol $(\mathrm{cm})$} \\
\hline & F.Alam & Urea & Phonska & $\mathrm{KCl}$ & $\begin{array}{l}\text { Jml tongkol per } \\
\text { ha }\end{array}$ & Panjang Tongkol & \\
\hline A & 0 & 0 & 0 & 0 & $24.952 \mathrm{c}$ & $13.080 \mathrm{~b}$ & 3.79 \\
\hline B & 0 & 450 & 0 & 0 & $46.666 \mathrm{ab}$ & $13.893 \mathrm{ab}$ & $4.13 \mathrm{~b}$ \\
\hline $\mathrm{C}$ & 0 & 350 & 450 & 0 & $43.238 \mathrm{ab}$ & $17.26 \mathrm{a}$ & $4.10 \mathrm{~b}$ \\
\hline D & 100 & 450 & 0 & 0 & $42.952 \mathrm{ab}$ & $15.80 \mathrm{ab}$ & $4.16 \mathrm{~b}$ \\
\hline $\mathrm{E}$ & 200 & 450 & 0 & 0 & $42.857 \mathrm{ab}$ & $15.19 \mathrm{ab}$ & $4.12 \mathrm{~b}$ \\
\hline $\mathrm{F}$ & 300 & 450 & 0 & 0 & $40.095 \mathrm{~b}$ & $16.70 \mathrm{a}$ & $4.35 \mathrm{a}$ \\
\hline G & 100 & 450 & 0 & 100 & $54.761 \mathrm{a}$ & $14.48 \mathrm{ab}$ & $4.36 \mathrm{a}$ \\
\hline $\mathrm{H}$ & 200 & 450 & 0 & 100 & $42.857 \mathrm{ab}$ & $15.24 \mathrm{ab}$ & $4.23 \mathrm{ab}$ \\
\hline I & 300 & 450 & 0 & 100 & $44.000 \mathrm{ab}$ & $15.07 \mathrm{ab}$ & $4,25 \mathrm{ab}$ \\
\hline \multicolumn{5}{|c|}{$\mathrm{KK}(\mathrm{CV})$} & 10.95 & 7.02 & 2,25 \\
\hline
\end{tabular}

Keterangan:

Angka selajur yang diikuti oleh huruf yang sama tidak berbeda nyata berdasarkan uji lanjut DMRT pada taraf 0.05. 


\section{Komponen Hasil}

Hasil panen bentuk tongkol, tertinggi ditunjukkan per;akuan G (100 Fosfat Alam + $450 \mathrm{~kg}$ Urea $+100 \mathrm{~kg} \mathrm{KCl} / \mathrm{ha}$ ) tidak berbeda nyata dengan pupuk rekomendasi perlakuan C (350kg Urea + 450 Phoska). Perlakuan bobot per tongkol tidak berbeda nyata adalah perlakuan D (100 kg Fosfat Alam + $450 \mathrm{~kg}$

Tabel 6. Pengamatan Bobot Tongkol dan Hasil Pipilan Kering Efektifitas Pupuk Anorganik Fosfat Alam

\begin{tabular}{|c|c|c|c|c|c|c|}
\hline & & & & 10 & Alam & \\
\hline \multirow[t]{2}{*}{ Perlk } & \multicolumn{4}{|c|}{ Jenis dan Dosisi Pupuk (kg/ha) } & \multicolumn{2}{|c|}{ Hasil Pengamatan } \\
\hline & $\begin{array}{l}\text { Fosfat } \\
\text { Alam }\end{array}$ & Urea & Phonska & $\mathrm{KCl}$ & $\begin{array}{c}\text { Bobot Tongkol } \\
\text { (kg/petak) }\end{array}$ & $\begin{array}{c}\text { Hasil pipilan } \\
\text { Kering t/ha }\end{array}$ \\
\hline A & 0 & 0 & 0 & 0 & $121.33 \mathrm{~d}$ & $2.19 \mathrm{~d}$ \\
\hline B & 0 & 450 & 0 & 0 & $206.67 \mathrm{ab}$ & $6.71 \mathrm{abc}$ \\
\hline $\mathrm{C}$ & 0 & 350 & 450 & 0 & $216.67 \mathrm{a}$ & $7.66 \mathrm{a}$ \\
\hline $\mathrm{D}$ & 100 & 450 & 0 & 0 & $173.67 \mathrm{abc}$ & $6.09 \mathrm{abc}$ \\
\hline $\mathrm{E}$ & 200 & 450 & 0 & 0 & $148.67 \mathrm{~cd}$ & $5.66 \mathrm{c}$ \\
\hline $\mathrm{F}$ & 300 & 450 & 0 & 0 & $184.67 \mathrm{abc}$ & $5.71 \mathrm{bc}$ \\
\hline $\mathrm{G}$ & 100 & 450 & 0 & 100 & $211.33 \mathrm{a}$ & $7.90 \mathrm{a}$ \\
\hline $\mathrm{H}$ & 200 & 450 & 0 & 100 & $184.00 \mathrm{bcd}$ & $6.47 \mathrm{abc}$ \\
\hline I & 300 & 450 & 0 & 100 & $161.33 \mathrm{bcd}$ & $6.14 \mathrm{abc}$ \\
\hline & & $\mathrm{KK}(\mathrm{C}$ & & & 14.12 & 14.93 \\
\hline
\end{tabular}

Keterangan:

Angka selajur yang diikuti oleh huruf yang sama tidak berbeda nyata berdasarkan uji lanjut DMRT pada taraf 0.05 .

Hasil panen pipilan kering, produksi tinggi diantara perlakuan pupuk Fosfat Alam ditunjukkan perlakuan pada G (100kg Fosfat Alam $+450 \mathrm{~kg}$ Urea $+100 \mathrm{~kg} \mathrm{KCl} / \mathrm{ha})$ dengan produksi 7,49 t/ha.tidak berbeda nyata dengan pupuk rekomendasi perlakuan C ( $350 \mathrm{~kg}$ Urea $+50 \mathrm{~kg}$ Phoska/ha) produksi 7,66 t/ha. Produksi tertinggi tidak berbeda nyata pada perlakuan Fosfat Alam pada perlakuan D ( $100 \mathrm{~kg}$ Fosfat Alam + $450 \mathrm{~kg}$ Urea), perlakuan H (200 kg Fosfat Alam $+450 \mathrm{~kg}$ Urea $+100 \mathrm{~kg} \mathrm{KCl} / \mathrm{ha})$ dan perlakuan I (200kg Fosfat Alam $+450 \mathrm{~kg}$ Urea $100 \mathrm{~kg} \mathrm{KCl}$ ).

Produksi pipilan kering per hektar, menunjukkan pada perlakuan pupuk rekomendasi Urea 350 + Phonska $450 \mathrm{~kg} / \mathrm{ha}$ dengan produksi $7.66 \mathrm{t} / \mathrm{ha}$ dan perlakuan dosis Fosfat Alam perlakuan G (Fosfat Alam $100+$ Urea $450+\mathrm{KCl} 100 \mathrm{~kg} / \mathrm{ha}$ ) hasil 7.90 t/ha. Menunjukkan hasil tertinggi per hektar tidak berbeda nyata dengan dosis pupuk rekomendasi. Dari hasil tersebut pupuk Fosfat Alam dapat mensubstitusi aplikasi
Urea/ha) dan perlakuan F (300kg Fosfat Alam $+450 \mathrm{~kg}$ Urea/ha). Menurut Purwa (2007), bahwa pada saat memasuki fase generatif tanaman bunga dan buah Unsur Fosfat yang berperan dalam pembentukan bunga, buah dan dapat meningkatkan produksi biji-bijian. pupuk Phonska dengan ketentuan dosis ada penambahan dosis pupuk Urea 450 dan $\mathrm{KCl}$ $100 \mathrm{~kg} / \mathrm{ha}$ dari pupuk rekomendasi yang menggunakan Phonska 450 dan Urea 350/ha. Gardner et al dalam Dahlan dan Arya (2008), mengemukakan bahwa semakin tinggi hasil fotosintesis yang dihasilkan oleh tanaman maka semakin besar pula penimbunan cadangan makanan yang ditranslokasikan ke biji dengan asumsi bahwa faktor lain seperti cahaya, air, suhu, dan hara dalam keadaan optimal.

\section{Relative Agronomis Effectiveness (RAE)}

Perlakuan dengan pupuk Fosfat Alam yang memberikan $\mathrm{RAE}>100$, nilai $\mathrm{RAE}$ hasil tertinggi ditunjukkan pada aplikasi Fosfat alam pada dosis $(100+$ urea $450+$ $\mathrm{KCl} 100 \mathrm{~kg} / \mathrm{ha}$ ) dengan nilai 117,26. Dan nilai RAE pada pupuk rekomendasi (Urea 350 + Phonska $450 \mathrm{~kg} / \mathrm{ha}$ ) memberikan nilai 121.02. Pada perlakuan dosis pupuk Fosfat Alam lainya nilai RAE $<100$, sehingga tidak 
bisa direkomendasi untuk dosis pemupukan

(Tabel 7).

Tabel 7. Nilai RAE Uji Efektifitas Pupuk Anorganik Fosfat Alam.

\begin{tabular}{ccccccc}
\hline Perlk & \multicolumn{3}{c}{ Jenis dan Dosisi Pupuk (kg/ha) } & \multicolumn{2}{c}{ Hasil Pengamatan } \\
\cline { 2 - 6 } & $\begin{array}{c}\text { Fosfat } \\
\text { Alam }\end{array}$ & Urea & Phonska & KCl & Hasil pipilan Kering t/ha & Nilai RAE \\
\hline A & 0 & 0 & 0 & 0 & $2.19 \mathrm{~d}$ & - \\
B & 0 & 450 & 0 & 0 & $6.71 \mathrm{abc}$ & 82,63 \\
C & 0 & 350 & 450 & 0 & $7.66 \mathrm{a}$ & 100 \\
D & 100 & 450 & 0 & 0 & $6.09 \mathrm{abc}$ & 71,30 \\
E & 200 & 450 & 0 & 0 & $5.66 \mathrm{c}$ & 50,46 \\
F & 300 & 450 & 0 & 0 & $5.71 \mathrm{bc}$ & 64,35 \\
G & 100 & 450 & 0 & 100 & $7.90 \mathrm{a}$ & 104,39 \\
H & 200 & 450 & 0 & 100 & $7.17 \mathrm{abc}$ & 70,49 \\
I & 300 & 450 & 0 & 100 & $6.14 \mathrm{abc}$ & 72,21 \\
\hline
\end{tabular}

\section{Hama dan Penyakit}

Hasil pengamatan hama yang muncul adalah ulat pada tonggkol, dengan tingkat serangan $1 \%$ dan tidak berpengaruh terhadap hasil produksi jagung. Penyakit yang muncul pada pertanaman awal adalah putih/bule yang menyerang tanaman pada waktu umur 3 minggu, dapat dikendalikan dengan menunda pengairan/mengurangi kelembaban dan menggunakan varietas jagung yang tahan bule sehingga tidak mengakibatkan kerugian pada hasil, dengan tingkat serangan pada hamparan adalah $0,015 \%$. Penyakait karat daun mencul pada tanaman setelah berbuah umur 70 HST dengan tingkat serangan 5\%.

\section{Analisis Finansial}

Hasil analisa sederhana efektivitas Fosfat Alam pada tanaman jagung, menunjukkan pada perlakuan $\mathrm{G}$ (Fosfat Alam 100 + Urea $450 \mathrm{~kg}+\mathrm{KCl} 100 \mathrm{~kg} / \mathrm{ha}$ ) $\mathrm{B} / \mathrm{C}$ ratio 1,23 . Pada dosis rekomendasi perlakuan C (Urea 350 + Phonska 450 $\mathrm{kg} / \mathrm{ha}) \mathrm{B} / \mathrm{C}$ ratio 1.22 . Pendapatan yang diproleh pada perlakuan Fosfat Alam Rp 15.700.000, pada pupuk rekomendasi pendapatan $\mathrm{Rp}$ 15.141.000.

\section{KESIMPULAN}

1. Aplikasi pupuk fosfat alam berpengaruh terhadap tinggi tamanan, panjang tongkol, diameter tongkol dan bobot tongkol basah, tetapi tidak berbeda dengan dosis

15 Jurnal Agriekstensia Vol. 18 No. 1 Juli 2019 pupuk rekomendasi perlakuan C (Urea 350 + Phoska $450 \mathrm{~kg} / \mathrm{ha}$ ).

2. Hasil Pipilan kering tertinggi ditunjukkan aplikasi Fosfat Alam pada perlakuan G (Fosfat Alam $100+$ Urea $450+\mathrm{KCl} 100$ $\mathrm{kg} / \mathrm{ha}$ ), produksi 7,90 t/ha dengan $\mathrm{B} / \mathrm{C}$ ratio 1,23 tidak berbeda pada pupuk rekomendasi perlakuan C (Urea $350+$ Phoska $450 \mathrm{~kg} / \mathrm{ha}$ ) hasil pipilan kering 7,66 t/ha dengan B/C Ratio 2,22. Nilai RAE menunjukkan nilai 104,39 pada perlakuan G (Fosfat Alam $100+$ Urea $450+\mathrm{KCl} 100 \mathrm{~kg} / \mathrm{ha}$ ).

3. Pupuk anorganik Fosfat Alam kandungan $\mathrm{P}_{2} \mathrm{O}_{5} 15,70 \%$ dapat digunakan sebagai subtitusi / penganti pupuk $\mathrm{P}$ (Fosfat) dengan dosis $100 \mathrm{~kg} / \mathrm{ha}, \quad$ dalam kombinasi pupuk (Fosfat Alam $100+$ Urea $450+\mathrm{KCl} 100 \mathrm{~kg} / \mathrm{ha}$ )

\section{Ucapan Terima Kasih}

PT Langgeng Lestari Nusantara atas kerjasamanya, telah mempercayai kami uji efektivitas Fosfat Alam pada tanaman jagung

\section{DAFTAR PUSTAKA}

Badan Pusat Statistik, 2016. Produksi Padi, Jagung dan Kedelai Tahun 2015. http://www.bps.go.id/brs_file/aram_0 1 jul13.pdf. Diakses pada tanggal 28 September 2017. 
Balai Penelitian Tanah. Kandungan Potensial Phosphat Alam. download pada tanggal 5 Juli. 2018.

Dahlan dan Arya, Z.P, 2008. Pengaruh Jarak Tanam Pagar Berganda terhadap Pertumbuhan Dan Produksi Tanaman Jagung. Jurnal Aristem. Gowa.

Damanik, M.M.B., Bachtiar E.H., Fauzi, Sarifuddin, dan Hamidah H., 2011. Kesuburan Tanah dan Pemupukan. USU Press, Medan. p 262.

Djaenudin. D, Marwan. H, H. Subagyo, A. Mulyani, dan N. Suharta. Kriteria Kesesuaian Lahan untuk Komoditas Pertanian. Badan Litbangtan. Pusat Penelitian Tanah dan Agroklimat. Bogor. 264 hal.

Idris, K. 1993. Evaluasi Agronomik Fosfat Alam dari Jawa dan Pengapuran pada Tanah-Tanah Masam dengan Teknik Isotop dalam Risalah Pertemuan Ilmiah: Aplikasi isotop dan Radiasi dalam Bidang Pertanian, Peternakan dan Biologi. Jakarta, 9-10 Desember 1992. Badan Tenaga Atom National.

Karama, S. 2000. Tanah Sakit Perlu Sistem Pertanian Organik. Mimbar 27 (305) : 8. P3GI. 2006. Teknologi Pengkomposan dengan Inopos. Pasuruan.

Kasno, A., dan A. Sofyan. 1998. Prospek Penggunaan pupuk P-alam pada Tanah Masam Lahan Kering. Dalam: Prosiding Seminar Nasional dan Pertemuan Tahunan Komda HITI. Komisariat Daerah (KOMDA) Jawa Timur: 195-201.

Machay, A. D. J. K. Syers. and P.E.H. Gregg. 1984. Ability of Chemical
Extraction Procedures to Assess The Agronomic Effectiveness of Phosphate Rock Material. New Zealand Journal of Agricultural Research 27: 219 - 230.

Pian, H. 2010. Efek Toksisitas Logam Bobot Timbal (pb), Merkuri, Kadmium. http://pianhervian.wordpress.com/2 017/15/21/efek-toksisitas-logambobot-timbal-pb-merkuri-hgkadmium-cd/

Purnomo, J. 2007. Respon Tanaman Jagung terhadap Pemberian Pupuk Fosfat pada Tanah Inceptisol dari Bogor. Dalam: D. Subardja, R. Saraswati, Mamat H.S., P. Setyanto, D. Setyorini, Wahyunto, M. Noor dan Irawan (Eds). Pros. Lokakarya Nasional Inovasi Teknologi Pertanian Mendukung Hari Pangan Sedunia 2007. Bandar Lampung, 25-26 Oktober 2007, hal. 377-394.

Purwa, DR, 2007. Petunjuk Pemupukan. Agro Media. Jakarta

Puslitanak. 2004. Sumber Daya Lahan Indonesia dan Pengelolaannya. Badan Penelitian dan pengembangan Pertanian. Departemen Pertanian.Bogor. 242 hal.

Sugih C.S. 2011. Mineral Tanaman. http://www.sugihciptasantosa.com/ html.

Tisdale, S.L., W.L. Nelson, dan J.D. Beaton, 1985. Soil fertility and Fertilizers. 4th ed. Macmillan Pub. Co., New York.

Zainal, A dan F Kasijadi. 2009. Inovasi Teknologi Jagung. Badan Litbang Pertanian. BPTP Jawa Timur. 